\title{
A Survey on Pigment Content in Commercial Formula Feeds for Poultry in Japan
}

\author{
Minoru Yoshida ${ }^{1)}$ and Paul, E. Donnelly ${ }^{2)}$ \\ ${ }^{11}$ National Institute of Animal Health, Yatabe, Tsukuba, Ibaraki, Japan 305 \\ ${ }^{2)}$ Ruakura Animal Research Station, Private Bag, Hamilton, New Zealand
}

It is well knwon that dietary xanthophyll pigment content has a direct influence on yolk colour of eggs. Some of the Japanese consumers has been complaining that most of yolks of commercial table eggs sold in the present Japanese market are too light in colour. How ever, little information is available indicating how dark the colour of the yolks is in commercial table eggs, or showing what is the colour of the yolks which satisfy the consumers complaining about it.

Results of a survey in 1968 indicated that the colour of the yolks in eggs sold in retail stores in Gifu area in Japan was, on average, 8.99 by Roche Yolk Colour Fan (RCF) ${ }^{1}$. In winter, the colour was somewhat darker, being 9.94, than that in summer, being 8.54. Another survay in 1980 of one of the authors ${ }^{2}$ showed that members of Japanese Society of Food and Nutrition in Tokyo area was satisfied with yolk colour of 9.3 by RCF. The eggs tested in the latter survey were laid by hens fed a formula feed containing $18.0 \mathrm{ppm}$ of total xanthophyll in National Institute of Animal Industry.

In this paper, results from a survey of the pigment content in commercial formula feed for poultry in Japan are presented.

\section{Materials and Methods}

One sample of chick starter feeds, 3 samples of broiler finisher feeds, and 6 samples of feeds for laying hens were taken in each of 4 seasons randomly from feed manufacturing factories in Tokyo, Osaka, and Kyushu areas in Japan. The samples were packed in coloured polyethylene bag under nitrogen and sent to Japan Food Research Laboratories, where the contents of total xanthophyll as described by KoHLER et al. ${ }^{3 \text { ) }}$ and of non-epoxide pigmenting xanthophyll as given by Livingston et al. ${ }^{4)}$ were analyzed. The sampling was started on October, 1981, and ended on August, 1982.

The data were firstly analyzed statistically as randomized block design to compare contents of total xanthophyll and non-epoxide pigmenting xanthophyll in 120 samples as blocks. Then, the data were analyzed as three factorial design with uneven but proportional replications $^{5}$. Types of feed, seasons and areas of sampling were the 3 factors. In this factorial design, values of total xanthophyll and non-epoxide pigmenting xanthophyll were analyzed individually, then they were treated as duplicated values of the pigment. An electronic computer ACOS $800 \mathrm{II}$ of the Computing Center for Research in Agriculture, Forestry and Fishery was used in the analysis of variance with a program written by one of the authors. 


\section{Results and Discussion}

Xanthophyll results are given in Table 1. On average there was no significant difference between the total $(12.1 \mathrm{mg} / \mathrm{kg})$ and the non-epoxide $(12.2 \mathrm{mg} / \mathrm{kg})$ xanthophyll content of feeds; the correlation between the two sets of results was 0.975 . The two sets of results were treated as duplicates in the tactorial analysis.

In Table 2, analyses of variance of the three-factor factorial design are presented; the error variance, $e_{2}$, was from between duplicate values In this design, factor $\mathrm{A}, i$. $e$, the effect among types of feed, was treated as a fixed effect, while factors B and C, i.e., effects among seasons and among areas of sampling, were treated as random-effects. The main effect $\mathrm{A}$ was $\mathrm{F}$-tested as $\mathrm{MS}_{1} / \mathrm{MS}_{2}$; the main effects $\mathrm{B}$ and $\mathrm{C}$ were $\mathrm{F}$-tested against interactions, $\mathrm{AxB}$ and $\mathrm{AxC}$, respectively. The main effects $\mathrm{A}$ and $\mathrm{B}$ were significant, while the

Table 1. Content of pigment $(\mathrm{mg} / \mathrm{kg})$ in samples

\begin{tabular}{|c|c|c|c|c|c|c|c|c|c|c|}
\hline \multirow{2}{*}{ Area } & \multirow{2}{*}{\multicolumn{2}{|c|}{$\begin{array}{l}\text { Type of } \\
\text { feed }\end{array}$}} & \multicolumn{4}{|c|}{ Total xanthophyll } & \multicolumn{4}{|c|}{ Non-epoxide xanthophyll } \\
\hline & & & Autumn & Winter & Spring & Summer & Autumn & Winter & Spring & Summer \\
\hline \multirow[t]{10}{*}{ Tokyo } & Chick & 1 & 11.0 & 9.1 & 11.0 & 7.6 & 12.0 & 8.6 & 11.3 & 8.0 \\
\hline & Broiler & 1 & 7.7 & 12.6 & 9.5 & 8.1 & 8.1 & 11.7 & 10.1 & 8.8 \\
\hline & & 2 & 8.5 & 10.6 & 14.0 & 7.6 & 8.7 & 10.3 & 14. 2 & 7.7 \\
\hline & & 3 & 9.4 & 7.7 & 12.2 & 9.7 & 9.0 & 7.1 & 12.3 & 10.4 \\
\hline & Layer & 1 & 13.7 & 10.3 & 18.7 & 7.9 & 13.8 & 10.0 & 19.6 & 8.3 \\
\hline & & 2 & 12.3 & 14.8 & 14.6 & 9.6 & 12.7 & 14.5 & 14.6 & 11.0 \\
\hline & & 3 & 12.2 & 16.0 & 14.3 & 12.4 & 11.0 & 13.8 & 14.2 & 13.8 \\
\hline & & 4 & 11.1 & 16.3 & 17.5 & 14.4 & 11.2 & 15.5 & 17.6 & 15.2 \\
\hline & & 5 & 11.0 & 16.2 & 18.8 & 11.7 & 10.9 & 18.5 & 19.2 & 12.0 \\
\hline & & 6 & 10.1 & 12.2 & 10.7 & 8.7 & 11.7 & 11.9 & 10.3 & 8.9 \\
\hline \multirow[t]{10}{*}{ Osaka } & Chick & 1 & 11.4 & 15.9 & 13.1 & 7.4 & 11.9 & 15.3 & 13.1 & 8.0 \\
\hline & Broiler & 1 & 11.1 & 15.9 & 12.4 & 10.2 & 12.6 & 16.2 & 12.3 & 10.2 \\
\hline & & 2 & 10.1 & 10.9 & 12.6 & 7.6 & 10.2 & 9.9 & 13.1 & 7.6 \\
\hline & & 3 & 9.8 & 11.0 & 12.2 & 7.4 & 11.4 & 10.9 & 12.6 & 7.1 \\
\hline & Layer & 1 & 20.2 & 11.9 & 15.5 & 7.4 & 20.3 & 12.5 & 15.9 & 8.0 \\
\hline & & 2 & 12.5 & 11.1 & 16.6 & 10.7 & 12.4 & 11.4 & 16.9 & 11.3 \\
\hline & & 3 & 15.1 & 9.0 & 14.3 & 12.0 & 14.9 & 9.5 & 14.2 & 9.9 \\
\hline & & 4 & 11.7 & 9.6 & 9.9 & 11.9 & 12.1 & 9.9 & 9.8 & 12.5 \\
\hline & & 5 & 16.1 & 8.8 & 12.9 & 12.8 & 16.4 & 9.9 & 13.1 & 14.1 \\
\hline & & 6 & 12.6 & 10.3 & 13.8 & 14.6 & 12.5 & 11.0 & 14.5 & 13.5 \\
\hline \multirow[t]{10}{*}{ Kyushu } & Chick & 1 & 12.6 & 7.2 & 12.2 & 9.5 & 12.5 & 7.9 & 12.4 & 10.4 \\
\hline & Broiler & 1 & 10.6 & 9.5 & 13.7 & 9.0 & 10.4 & 9.4 & 14.5 & 8.9 \\
\hline & & 2 & 8.6 & 11.8 & 13.3 & 7.9 & 9.0 & 12.9 & 13.8 & 6.2 \\
\hline & & 3 & 10.2 & 9.8 & 12.3 & 8.2 & 10.1 & 8.7 & 12.2 & 8.1 \\
\hline & Layer & 1 & 8.8 & 9.3 & 16.5 & 7.7 & 8.5 & 8. 6 & 17.1 & 9.0 \\
\hline & & 2 & 12.7 & 10.0 & 15.2 & 13.9 & 12.4 & 10.3 & 15.9 & 13.3 \\
\hline & & 3 & 14.6 & 10.4 & 15.2 & 13.2 & 13.9 & 11.3 & 15.7 & 13.0 \\
\hline & & 4 & 15.8 & 14.7 & 13.4 & 13.4 & 15.1 & 15.3 & 13.9 & 13.3 \\
\hline & & 5 & 12.3 & 21.2 & 17.8 & 14.6 & 12.1 & 22.1 & 18.2 & 14.4 \\
\hline & & 6 & 16.3 & 11.9 & 20.4 & 13.4 & 15.7 & 12.9 & 20.8 & 11.7 \\
\hline
\end{tabular}


Table 2. Analysis of variance

\begin{tabular}{|c|c|c|c|c|}
\hline \multirow{2}{*}{ Source of variation } & \multicolumn{4}{|c|}{ Mean square } \\
\hline & $\begin{array}{l}\text { Degrees of } \\
\text { freedom }\end{array}$ & $\begin{array}{l}\text { Total } \\
\text { xanthophyll }\end{array}$ & $\begin{array}{l}\text { Non-epoxide } \\
\text { xanthophyll }\end{array}$ & $\begin{array}{l}\text { Mean of } \\
\text { xanthophyll }\end{array}$ \\
\hline Type of feed A & 2 & 111. $42^{* * 1)}$ & $111.12^{* *}$ & $111.22 * *$ \\
\hline Season $\quad B$ & 3 & 73. $04 * *$ & $80.56 * *$ & $76.66^{* *}$ \\
\hline Area & 2 & 4. 05 & 3.43 & 3.68 \\
\hline $\mathrm{A} \times \mathrm{B}$ & 6 & 3.92 & 2.92 & 3.27 \\
\hline $\mathrm{A} \times \mathrm{C}$ & 4 & 7.76 & 7.23 & 7.46 \\
\hline $\mathrm{B} \times \mathrm{C}$ & 6 & 9.35 & 7.97 & 8.12 \\
\hline $\mathrm{A} \times \mathrm{B} \times \mathrm{C}$ & 12 & 8. 03 & 6.28 & 7.07 \\
\hline $\mathrm{R}(\mathrm{ABC})$ & 84 & 6.05 & 6.36 & 6. $10^{* *}$ \\
\hline $\mathrm{e}_{2}$ & 120 & & & 0.249 \\
\hline $\mathrm{MS}_{1}{ }^{11}$ & 2 & 119. $46^{* *}$ & $117.40 * *$ & 118. $30^{* *}$ \\
\hline $\mathrm{MS}_{2}$ & 7 & 11.69 & 10.15 & 10.73 \\
\hline
\end{tabular}

1) Significant at $1 \%$ level.

2) $\mathrm{MS}_{1}=\mathrm{MS}_{\mathrm{A}}+\mathrm{MS}_{\mathrm{A} \times \mathrm{B} \times \mathrm{C}}, \mathrm{MS}_{2}=\mathrm{MS}_{\mathrm{A} \times \mathrm{B}}+\mathrm{MS}_{\mathrm{A} \times \mathrm{C}}$.

Table 3. Pigment content $(\mathrm{mg} / \mathrm{kg}$ ) of feeds by season and ration

\begin{tabular}{|c|c|c|c|c|c|}
\hline \multirow{2}{*}{ Pigment Type of feed } & \multicolumn{4}{|c|}{ Season } & \multirow{2}{*}{ Mean'1) } \\
\hline & Autumn & Winter & Spring & Summer & \\
\hline \multicolumn{6}{|l|}{ Total xanthophyll: } \\
\hline Chick & 11.7 & 10.7 & 12.1 & 8.2 & $10.7^{b}$ \\
\hline Broiler & 9.6 & 11.1 & 12.5 & 8.4 & $10.4^{b}$ \\
\hline Layer & 13.3 & 12.6 & 15.3 & 11.7 & $13.2^{\mathrm{a}}$ \\
\hline \multicolumn{6}{|l|}{ Non-epoxide xanthophyll: } \\
\hline Chick & 12.1 & 10.6 & 12.3 & 8.8 & 11. $0^{\mathrm{b}}$ \\
\hline Broiler & 9.9 & 10.8 & 12.8 & 8. 3 & $10.5^{b}$ \\
\hline Layer & 13.2 & 12.7 & 15. 6 & 11.8 & $13.4^{\mathrm{a}}$ \\
\hline \multicolumn{6}{|l|}{ Mean of xanthophyll: } \\
\hline Chick & 11.9 & 10.7 & 12.2 & 8.5 & $10.8^{b}$ \\
\hline Broiler & 9.8 & 10.9 & 12.6 & 8.4 & $10.4^{b}$ \\
\hline Layer & 13.2 & 12.7 & 15.5 & 11.8 & $13.3^{\mathrm{a}}$ \\
\hline Mean $^{11}$ & $12.1^{\mathrm{b}}$ & $12.0^{\mathrm{b}}$ & $14.3^{\mathrm{a}}$ & $10.4^{c}$ & \\
\hline
\end{tabular}

1) Values having different superscript were different at $1 \%$ level.

main effect $\mathrm{C}$ and all of the interactions were not significant. The variance of replication, $\mathrm{R}(\mathrm{ABC})$, indicated the variation among samples of the same type of feed from different feed manufacturing factories at the same season in the same area. The variance was $F$ tested against chemical error, $e_{2}$, and was highly significant.

In Table 3, average contents of total xanthophyll and non-epoxide xanthophyll in each type of feed for each season are presented. On average, formula feeds for laying hens contained $13.3 \mathrm{mg} / \mathrm{kg}$ of xanthopyll; this was significantly higher than the levels in feeds for starting chicks and for broilers. Ration xanthophyll levels of $13 \mathrm{mg} / \mathrm{kg}$ would result in the production of eggs with yolk colours of about $7-8$ by $\mathrm{RCF}^{6,7)}$. Levels as high as $18 \mathrm{mg} / \mathrm{kg}$ would be required to achieve a satisfactory yolk color of 9 . 
Additional pigment can be supplied either by replacing cereals having no pigment such as milo and rice with yellow corn, or by supplementing with pigmenting agents. The two major supplementary sources of pigment in Japan are alfalfa (lucerne) meal (range in xanthophyll content 150 to $300 \mathrm{mg} / \mathrm{kg}$ for $17 \%$ crude protein product) and corn gluten meal $\left(180\right.$ to $400 \mathrm{mg} / \mathrm{kg}$ xanthophyll $\left.{ }^{6}\right)$. Leaf meal from China has also been used in rations but this product is no longer available. A further potential pigment concentrate for feed formulation in Japan is leaf protein concentrate prepared from green herbage. This product has a high xanthophyll content (range 950 to $1560 \mathrm{mg} / \mathrm{kg}^{7 \sim 9)}$ ). Studies have shown the efficiency of utilization by poultry of these xanthophylls to be similar to ${ }^{7,8)}$ or greater than ${ }^{9)}$, that for alfalfa meals. From the very high relative xanthophyll potency of $1092 \mathrm{mg} / \mathrm{kg}^{8)}$, it is calculated that only $1.6 \%$ of leaf protein concentrate would be required to provide a total ration level of $18 \mathrm{mg} / \mathrm{kg}$. Recent developments in the production of leaf protein concentrates in France, the USA and New Zealand suggest this product may become a substitute for dwindling supplies of leaf meals in Japan.

The seasonal variation of pigment content in poultry feeds was unexpected, and the reasons for this are not clear. Similar trends were observed in all types of feeds and in all the areas sampled, the variation was not due to a change in formulation in a certain feed manufacturing factory in a certain area. Yellow corn imported from the United States, from which most yellow corn for feed use in Japan has been imported, was judged to be much lighter in colour than usual, and was suspected to be one of the reasons for the drop in xanthophyll content in the summer season. Another factor may be release of rice stocked by the Government after last May. In contrast, however, about 200, 000 tons of yellow corn was imported from Thailand and South Africa, where dark-coloured yellow corn is produced. Most of the corn was included in feeds produced in the spring season, and this may be one of the reasons for the rise in xanthophyll in this season. The proportion of yellow corn and alfalfa meal, two major natural pigment sources, included in poultry feeds remained virtually unchanged in the last year. This seasonal variation in xanthophyll content indicates the necessity of more careful use of pigmenting agents in formula feeds, particularly for laying hens.

Finally, it is noted that results for xanthophyll and non-epoxide xanthophyll were, on average, indistinguishable. This may have been for two reasons; firstly the low levels of pigment in the materials being analysed and inherent variation in the procedures, and secondly because of a high proportion of corn and corn based products in the rations which have a high proportion of total xanthophylls comprised of lutein and zeaxanthin ${ }^{6}$. Regardless, both procedures seemed to be effective for determining xanthophyll content of formulated poultry feeds.

\section{Acknowledgment}

The authors express their deep appreciation to Mr. Takehiko Toshida, vice-directer of Tokyo Fertilizer and Feed Inspection Station, who took charge of the sampling.

\section{Reference}

1) Brant, A. W., S. Senda, and T. Takamlra (1966) Egg quality in Gifu city, Japan : Poult. Sci., 
48 : 1968-1976.

2) Yoshida, M. (1981) Questionaire on peelability of shell, taste of egg yolk and albumen, and yolk colour of hard-cooked eggs (in Japanese) : Japan. Poult. Sci., $18: 360-365$.

3) Kohler, G. O., Knowles, R. E., and Livingston, A. L. (1967) An improved analytical procedure for the determination of xanthophyll: J.A. O. A. C, $50: 707-711$.

4) Livingston, A. L., R. E. Knowles and G. O. Kohler (1973) Comparison of two methods for the analysis of pigmenting xanthophylls in dried plant meterials : J. A. O. A. C., 56 : 1378-1381.

5) Yoshida, M. (1975) Design of experiments for animal husbandry (in Japanese): Yokendo, Tokyo, Japan.

6) Marusich, W. L. and Bauernfeind, J. C. (1981) Oxycarotenoids in poultry feeds. In oxycarotenoids as colourants and vitamin A precursors (Technological and nutritional applications). Ed. by J. C. Bauernfeind. Academic Press. p. 319.

7) Blum, J.C. and Gullaumin, S. (1979) Effectiveness of xanthophylls from different sources in egg and chicken colouring. Matieres Premieres et aliminentation Des Volailles. October 19. p. $7-21$ (Translated from French).

8) Yoshida, M. and H. Hoshil (1982) Nutritive and economic evaluation of leaf protein concentrates produced in New Zealand (in Japanese) : Japan. Poult. Sci., $19: 45-52$.

9) Kumicky, D. D., Livingston, A. L., Knowles, R. E., Kohler, G. O., Guenther, E., Olson, O. E., and Carlson, C. W. (1977). Xanthophyll availability of alfalfa leaf protein concentrate for broilers and laying hens. Poult. Sci., 56 : 1504-1509.

\title{
日本で市販されている養鵎用飼料中の色素含量に関する調査
}

\author{
吉四美1・ポール，E．ドネリー2 \\ 1) 農林水産省毭畜衛生試験埸, 谷由1部, 茨城 305 \\ 2)ルアクラ畜産試験場，ハミルトン、ニェージーランド
}

昭和 56 年秋, 冬および昭和 57 年春, 夏の 4 季にわた って，東京，大阪および九州の 3 地域で生産されて市販 された養鵎用飼料の色素含量を調査した。

サンプルは，各地域ごとに，4季それぞれについて， 育すう用飼料 1 点, ブロイラー仕上用飼料 3 点, 産卵鶏 用飼料 6 点, 計 10 点ずつ, 飼料工場から無作為に採集し た。総点数は 120 点となる。サンプルは, 日本食品分析 センターにおいて，総キサントフィルと非ェポキサイド ・キサントフィル含量を測定した。3元配置法で反復数が 等しくないが比例している場合として分散分析した。

同一飼料の総キサントフィルと非エポキサイド・キサ ントフィルの含量には，統計的に有意な差は認められな かった。どちらの場合でも，飼料間差と，季節間差が有 意であったが, 地域間差と，すべての交互作用は有意で はなかった。

そこで，飼料ごと，季節ごとの平均值を求めた。育す
う用, ブロイラー用，産卵鶏用の各飼料の色素含量の 1

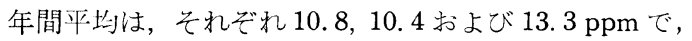
産卵鶏用飼料で高かった $(\mathrm{P}<0.01)$ 。一方, 秋, 冬, 春, 夏の季節ごとの平均は，それぞれ $12.1 ， 12.0 ， 14.3$ お よび $10.4 \mathrm{ppm}$ であって，秋と冬の含量に比し，春では 高く，夏に低くなっており，この差は有意であった（P $<0.01)$ 。

消費者に好まれる卵黄の着色度を調査した結果によれ ば，ロッシュ・ヨーク・カラー・ファンの評点で 9 であ り，この着色度の舀卵を生産するためには，飼料中の総 キサントフィル今最は $18 \mathrm{ppm}$ が必装とされている。こ れと比較すると川服されている養獣朋飤料の色素分星は 十分とはいえない。㸴節間の色尖今翼の変化の原因に一 いて考察した。

（家禽会訫，20，110～114，1983） 